\title{
EFFECT OF OSMOTIC STRESS AND POST-STRESS RECOVERY ON THE CONTENT OF PHENOLICS AND PROPERTIES OF ANTIOXIDANTS IN GERMINATING SEEDS OF GRAPEVINE VITIS CALIFORNICA
}

\author{
STANiSŁAW WEIDNER ${ }^{1 *}$, WiOLETTA BROSOWSKA-ARENDT ${ }^{1}$, WOJCIECH SZCZECHURA ${ }^{1}$, \\ MAGDALENA KARAMAĆ ${ }^{2}$, AgNiESZKA KOSIŃSKA ${ }^{2}$, RYSZARD AMAROWICZ ${ }^{2}$ \\ ${ }^{1}$ Department of Biochemistry, Faculty of Biology, \\ University of Warmia and Mazury in Olsztyn \\ M. Oczapowskiego 1A, 10-957 Olsztyn-Kortowo, Poland \\ * e-mail: weidner@uwm.edu.pl \\ 2 Division of Food Science, \\ Institute of Animal Reproduction and Food Research of the Polish Academy of Sciences \\ Tuwima 10, 10-747 Olsztyn, Poland
}

(Received: March 30, 2010. Accepted: January 1, 2011)

\begin{abstract}
The tested material consisted of grapevine Vitis californica stratified seeds germinated under optimum conditions $\left(+25^{\circ} \mathrm{C}\right.$ in water), under osmotic stress $(-0.2 \mathrm{MPa}$ in PEG solution) and submitted to recovery after stress $\left(+25^{\circ} \mathrm{C}\right.$ in water). The germinating seeds were determined to contain tannins, catechins and the following phenolic acids: gallic, caffeic, $p$-coumaric and ferulic. The acids occurred in free, ester- and glycoside-bound forms. The dominant form of phenolic acids was the ester-bound fraction. Gallic acid was the most abundant phenolic acid in germinating seeds, while ferulic acid appeared in the smallest amounts. Our analysis of tannins demonstrated that osmotic stress depressed their concentration. Presence of catechin group compounds such as catechin and epicatechin was also determined. In each sample epicatechin was dominant. The total concentration of catechin increased under stress conditions and declined during post-stress recovery. Catechins are a constituent of tannins and their increase under osmotic stress is most probably caused by the breakdown of some tannins in seeds germinating under stress conditions. Samples submitted to osmotic stress were also found to contain less of total phenolic compounds, whereas in samples which underwent post-stress recovery the total level of phenolic compounds increased. Compared to extracts from seeds germinating under optimum conditions, osmotic stress depressed the capacity of extract to scavenge $\mathrm{DPPH}^{\bullet}\left(2,2\right.$-diphenyl-1-picrylhydrazyl) and $\mathrm{ABTS}^{\bullet+}-2,2$-Azino-bis (3-etylbenzothiazoline-6-sulfonic acid) free radicals, but the antioxidant activity rose in seeds submitted to recovery after stress. Positive correlation was therefore demonstrated between the total content of phenolic acids in germinating grapevine seeds and the reducing power of extracts obtained from these seeds and their free radical scavenging activity. The results suggest that osmotic stress inhibits the activity of antioxidizing enzymes in germinating grapevine seeds. Thus, the antioxidative defence system is largely blocked under osmotic stress. It seems that a very high oxidoreductive potential in grapevine tissues prior to occurrence of osmotic stress is essential for maintaining proper homeostasis of oxidation and reduction reactions.
\end{abstract}

KEY WORDS: Vitis californica L., antioxidant system, oxidative stress, osmotic stress, recovery, phenolic compounds.

\section{INTRODUCTION}

Under natural conditions, plants can be exposed to a variety of environmental stresses, such as drought, low or high temperature, excessive salinity. These abiotic stress factors generate secondary stresses, i.e. osmotic and oxidative stress, which have negative influence on the plant, causing changes in its proper growth, development and metabolism (Bohnert et al. 1995). Depending on the inten- sity and duration of stress, such changes can be reversible or irreversible, leading in extreme cases to the plant's death (Piskornik 1994; Gwóźdź 1996). Environmental stresses are responsible for depressed yields and lower yield quality. Thus, it is necessary to conduct research focused on obtaining cultivars which would be more tolerant to adverse environmental factors. Water stress is one of these environmental factors that can considerably limit distribution of crops in the world. 
Antioxidants play an important role in plant resistance to abiotic stresses (Dixon and Paiva 1995), as they protect cells from free radicals (FR) and reactive oxygen species (ROS), which are produced in response to various environmental stresses and cause peroxidation of lipids, denaturation of proteins and DNA damage (Smirnoff 1998; Kranner et al. 2002; Mittler 2002). Antioxidative activity is demonstrated, for example, by phenolic compounds such as phenolic acids, flavonids and tannins, which are plant secondary metabolites (Oszmiański 1995). They are formed in the phenylpropanoid pathway, which is stimulated mainly by the enzyme phenylalanine ammonia-lyase (PAL; EC 4.3.1.5) (Dixon and Paiva 1995). In response to environmental stresses, the activity of PAL rises and the enzyme activates many genes engaged in synthesis of phenylpropanoids (Solecka 1997; Keles and Oncel 2002; Oh et al. 2009).

Phenolic acids usually occur in a form bound to the cell wall's sugars, organic acids or carbohydrates. Moreover, a high concentration of free phanolic acids in plant tissues can be toxic to plants (Harborne 1980). On the other hand, estrification and glycolization of phenolic acids enables plants to avoid the negative influence of these compounds accumulating in plant cells and tissues (Dixon and Paiva 1995).

Phenolic compounds can accumulate in plant cells during ontogeny, regulating development and germination of seeds. Accumulation of phenolic compounds can also occur under the influence of various environmental factors, when these substances protect plants from stresses. For instance, loss of germinating ability by seeds is positively correlated with an increase of phenolic compounds in seeds (Sreeramulu 1983; Weidner et al. 2002). In turn, environmental stress can cause a decline (Weidner et al. 2007, 2009b) or an increase (Wróbel et al. 2005; Weidner et al. 2009a) in the content of phenolic compounds in a cell. Phenolic compounds can scavenge free radicals (FR) and reactive oxygen species (ROS) (Amarowicz et al. 2000, 2004; Negro et al. 2003; Caillet et al. 2006; Amarowicz and Weidner 2009), they form complexes with the metals which catalyze oxygenation reaction and inhibit activity of oxidizing enzymes (Sokół-Łętowska 1997). Moreover, their antioxidant efficiency is much higher than that of tocopherol or ascorbate (Blokhina et al. 2003).

Plant adaptation to osmotic stress is an outcome of many different physiological and molecular mechanisms. The objective of the study was to investigate changes in the composition of phenolic compounds in seeds of Vitis californica, and to examine the differences in the antioxidant properties of extracts of phenolic compounds obtained from seeds growing under optimal conditions and under osmotic stress.

\section{MATERIAL AND METHODS}

\section{Stratification and germination of seeds under normal} and osmotic stress conditions

Experiments were conducted on Vitis californica seeds, supplied by Sandeman Seeds (France). Seeds were surface sterilized in $0.5 \%$ sodium hypochlorite for $20 \mathrm{~min}$ and washed with sterilized water. Stratification was conducted in a $1: 1$ mixture of sand and peat for 3 months at $+4^{\circ} \mathrm{C}$.
After stratification, 100 seeds were placed and germinated in a $140 \times 25 \mathrm{~mm}$ Petri dish lined with lignin layers soaked with $50 \mathrm{ml}$ water. Germination under optimum conditions $\left(+25^{\circ} \mathrm{C}\right)$ was conducted for 10 days. Seeds with radicles measuring about $1 \mathrm{~mm}$ underwent further germination. They were divided into two batches: one was germinated for another two days (sample $\mathrm{C}$ ); the other one was germinated under osmotic stress $(-0.2 \mathrm{MPa})$ for two days. In order to obtain $-0.2 \mathrm{MPa}$ at $+25^{\circ} \mathrm{C}$, PEG (polyethylene glycol, MW 8000 - Sigma) at a concentration of $119.46 \mathrm{~g} / 1$ was prepared. Some of the osmotic stress treated seeds were submitted to recovery (sample $\mathrm{S}+\mathrm{R}$ ). 100 seeds were germinated for two more days under optimum conditions.

\section{Extraction of phenolic compounds}

Phenolic compounds were extracted from the seeds three times into $80 \%(\mathrm{v} / \mathrm{v})$ acetone for $15 \mathrm{~min}$ at $80^{\circ} \mathrm{C}$, as described by Amarowicz et al. (1995). After evaporating the organic solvent in a rotary evaporator at $45^{\circ} \mathrm{C}$, the remaining aqueous solution was lyophilized.

\section{Determination of total phenolics}

The content of total phenolic compounds in the extracts was determined using Folin-Ciocalteau's reagent (Naczk and Shahidi 1989) and (+)-catechin was used as a standard.

\section{Separation and analysis of phenolic acids by HPLC}

Phenolic acids (free and those liberated from soluble esters or soluble glycosides) were isolated from the extracts according to the method previously described by Kryger et al. (1982), Zadernowski and Kozłowska (1983), and Weidner et al. (2000). Aqueous suspension of the methanolic extract (200 $\mathrm{mg}$ in $20 \mathrm{ml}$ ) was adjusted to $\mathrm{pH} 2$ with $6 \mathrm{M} \mathrm{HCl}$, and free phenolic acids were extracted five times into $20 \mathrm{ml}$ of diethyl ether using a separatory funnel. The ether extract was evaporated to dryness under vacuum at room temperature. The water solution was neutralized and then lyophilized. The residue was dissolved in $20 \mathrm{ml}$ of $2 \mathrm{M} \mathrm{NaOH}$ and hydrolyzed for $4 \mathrm{~h}$ in nitrogen atmosphere at room temperature. After acidification to $\mathrm{pH} 2$ using $6 \mathrm{M}$ $\mathrm{HCl}$, phenolic acids released from soluble esters were extracted five times from the hydrolyzate into $30 \mathrm{ml}$ of diethyl ether. Nine $\mathrm{ml}$ of $6 \mathrm{M} \mathrm{HCl}$ was added to the water solution, which was then placed in nitrogen atmosphere and hydrolyzed for $1 \mathrm{~h}$ in boiling water bath. Phenolic acids released from soluble glycosides were separated five times from the hydrolyzate into $45 \mathrm{ml}$ of diethyl ether. After ether evaporation, the dry residue was dissolved in $2 \mathrm{ml}$ of methanol and filtered through a $0.45 \mu \mathrm{m}$ nylon filter. The sample was injected onto an HPLC column. A Shimadzu HPLC system was employed: $\mathrm{LC}-10 \mathrm{ADV}_{\mathrm{P}}$ pump, photodiode array detector UV-VIS SPD - M10AV ${ }_{\mathrm{P}}$, oven $\mathrm{CTO}-10 \mathrm{ASV}_{\mathrm{P}}$, Controller SCL $-10 \mathrm{AV}_{\mathrm{P}}$. The conditions of the separations were as follows: pre-packed LUNA $\mathrm{C}_{18}$ column $(5 \mu \mathrm{m}, 4.6 \times 250 \mathrm{~mm}$; Phenomenex); mobile phase water-acetonitrile - acetic acid (88:10:2, v/v/v) (Amarowicz and Weidner 2001); flow rate of $1 \mathrm{ml} \cdot \mathrm{min}^{-1}$; injection volume of $20 \mu \mathrm{l}$; the detector was set at 280 and $320 \mathrm{~nm}$; the oven temperature was $20^{\circ} \mathrm{C}$.

\section{Determination of tannins with the vanillin method}

The content of tannins in the extract was determined using the modified Vanillin Assay (Price et al. 1978). The 
results were expressed as absorbance units at $500 \mathrm{~nm}$ per $\mathrm{mg}$ of extract $\left(\mathrm{A}_{500} / \mathrm{mg}\right)$. Briefly, to $0.5 \mathrm{ml}$ of extract, 2.5 $\mathrm{ml}$ of solution $\mathrm{B}$ (obtained by dissolving $0.5 \mathrm{~g}$ of vanillin in $100 \mathrm{ml}$ of solution A) was added. Solution A was made by adjusting $4 \mathrm{ml}$ of concentrated $\mathrm{HCl}$ to $100 \mathrm{ml}$ with methanol. The samples were left in the dark at room temperature for $20 \mathrm{~min}$, and then absorbance was measured at $500 \mathrm{~nm}$.

\section{Determination of tannins using the protein precipitation method}

The content of tannins in the extract was determined using the method described by Hagerman and Butler (1978). Briefly, $2 \mathrm{ml}$ of bovine serum albumin (BSA) solution (concentration $1 \mathrm{mg} \cdot \mathrm{ml}^{-1}$ in $0.2 \mathrm{M}$ acetate buffer at $\mathrm{pH}$ 5.5 containing $0.17 \mathrm{M} \mathrm{NaCl}$ ) was added to $1 \mathrm{ml}$ of the extract. The sample was left for $15 \mathrm{~min}$ at room temperature and then centrifuged $(5000 \times \mathrm{g})$. After $15 \mathrm{~min}$ of centrifugation, the supernatant was removed and the pellet was washed with $1 \mathrm{ml}$ acetate buffer and centrifuged again $(5000 \times \mathrm{g} / 15 \mathrm{~min})$. The sediment was dissolved in $4 \mathrm{ml}$ of solution containing: $1 \% \mathrm{SDS}$ and $5 \%$ TEA, and $1 \mathrm{ml}$ of $0.01 \mathrm{M} \mathrm{FeCl}_{3}$ in $0.01 \mathrm{M} \mathrm{HCl}$ was added. The samples were left at room temperature for $30 \mathrm{~min}$ and the absorbance was measured at $510 \mathrm{~nm}$. The results were expressed as absorbance units at $510 \mathrm{~nm}$ per $1 \mathrm{mg}$ of extract $\left(\mathrm{A}_{510} / \mathrm{mg}\right)$.

\section{Analysis of catechins with HPLC}

The same HPLC was used for catechin analysis. The separation was performed in a gradient system: solvent $\mathrm{A}$ : water-acetonitrile-acetic acid $(95: 5: 2, \mathrm{v} / \mathrm{v} / \mathrm{v})$; solvent $\mathrm{B}$ : water-acetonitrile-acetic acid $(58: 40: 2, \mathrm{v} / \mathrm{v} / \mathrm{v})$; linear gradient from 0 to $100 \% \mathrm{~B}$ for $50 \mathrm{~min}$ (Oszmiański and Bourzeix 1995); flow rate of $1 \mathrm{ml} / \mathrm{min}$; injection volume of $20 \mu \mathrm{l}$; the detector was set at $280 \mathrm{~nm}$; the oven temperature was $20^{\circ} \mathrm{C}$.

\section{Antiradical activity of seed extracts}

The antiradical activity was analyzed with the method described by Yen and Chen (1995). Briefly, 0.1-0.5 mg of an extract dissolved in $0.1 \mathrm{ml}$ of methanol was added to 2 $\mathrm{ml}$ of methanol; then, $0.25 \mathrm{ml}$ of a DPPH solution in the concentration of $1 \mathrm{mM}$ in methanol was added. The mixture was left in the dark at room temperature for $20 \mathrm{~min}$. After that time, absorbance was read at a wavelength of $517 \mathrm{~mm}$. The analysis was performed in three replicates.

\section{Reducing power of extracts}

Reducing power of phenolics present in the extracts was determined using the method described by Yen and Chen (1995). Briefly, $1 \mathrm{ml}$ of water containing 0.1-0.5 $\mathrm{mg}$ of an extract was pipetted into a tube. Next, $2.5 \mathrm{ml}$ of $0.2 \mathrm{M}$ phosphate buffer, $\mathrm{pH} 6.6$, and $2.5 \mathrm{ml}$ of $1 \%$ solution of potassium ferrocyanide were added. The mixture was incubated in a water bath at $50^{\circ} \mathrm{C}$ for $20 \mathrm{~min}$. Afterwards, 2.5 $\mathrm{ml}$ of $10 \%$ TCA (trichloroacetic acid) solution was added. To $2.5 \mathrm{ml}$ of this sample, $0.5 \mathrm{ml}$ of $0.1 \% \mathrm{FeCl}_{3}$ in distilled water was added. After $10 \mathrm{~min}$, absorbance was measured at a wavelength of $700 \mathrm{~nm}$. The analysis was performed in three replicates, and means for the values thus obtained were computed.

\section{Total Antioxidant Activity (TAA)}

The Total Antioxidant Activity of the extracts was determined according to the Trolox equivalent antioxidant activity (TEAC) assay described by Re et al. (1999). TAA was expressed as mmol Trolox equivalent/g of extract.

\section{Statistical evaluation}

All experiments were repeated four times, with three replicates for each sample. The presented values are the means of twelve determinations \pm SD. Statistically significant differences in the mean values were tested by Student's $t$-test.

\section{RESULTS}

The total content of phenolics in Vitis californica germinating seeds was determined taking advantage of a reaction with Folin-Ciocalteau's reagent. The results of this analysis are presented in Table 1. The highest concentration of phenolic compounds was found in seeds germinating under optimum conditions (sample $\mathrm{C}$ ), where it reached 1.58 $\mathrm{mg} / \mathrm{g}$ fresh weight of seeds. Under osmotic stress, the concentration of these compounds decreased to $0.91 \mathrm{mg} / \mathrm{g} \mathrm{FW}$ (sample S). A similar, decreasing tendency was found while analysing the results from calculating the total content of phenolics per dry weight of seeds or one gram of seed extract (Table 1). In seeds which underwent poststress recovery (sample $\mathrm{S}+\mathrm{R}$ ), the content of phenolics was observed to have risen to $0.95 \mathrm{mg} / \mathrm{g} \mathrm{FW}$, higher than in seeds germinating under osmotic stress (sample S). Similar tendencies were observed as resulting from the other computations (Table 1).

Modifications in the content of tannins were determined in Vitis californica seeds germinating under optimum conditions, osmotic stress and submitted to recovery after osmotic stress, using two methods. The results of the analyses performed with the vanillin method are presented in Table 2. The highest level of tannins was found in seeds germinating under optimum conditions (sample C), where it equalled $0.15 \mathrm{~A}_{500} / \mathrm{mg}$ of extract. The content of tannins

TABLE 1. The total content of phenolic compounds in Vitis californica seeds germinating under optimum conditions (C), osmotic stress conditions $(\mathrm{S})$ and submitted to recovery after the stress $(\mathrm{S}+\mathrm{R})$. An asterisk (*) marks significant differences between samples: $\mathrm{C}$ and $\mathrm{S}, \mathrm{S}$ and $\mathrm{S}+\mathrm{R}$ at $\mathrm{P}<0.05,(* *)$ at $\mathrm{P}<0.01,(* * *)$ at $\mathrm{P}<0.001 ;(\mathrm{n}=3)$.

\begin{tabular}{lccc}
\hline Sample & $\mathrm{mg} / \mathrm{g}$ of extract & $\mathrm{mg} / \mathrm{g}$ of DW & $\mathrm{mg} / \mathrm{g}$ of FW \\
\hline $\mathrm{C}$ & $154.99( \pm 0.63)$ & $5.32( \pm 0.02)$ & $1.58( \pm 0.01)$ \\
$\mathrm{S}$ & $34.79( \pm 0.55) * * *$ & $2.07( \pm 0.03) * * *$ & $0.91( \pm 0.01)^{* * *}$ \\
$\mathrm{~S}+\mathrm{R}$ & $54.73( \pm 0.49) * *$ & $2.16( \pm 0.02)^{* *}$ & $0.95( \pm 0.01)^{*}$ \\
\hline
\end{tabular}

TABLE 2. The total content of tannins according to the vanillin test in extracts of Vitis californica seeds germinating under optimum conditions (C), osmotic stress conditions (S) and submitted to recovery after the stress $(\mathrm{S}+\mathrm{R})$. An asterisk $(*)$ marks significant differences between samples: $\mathrm{C}$ and $\mathrm{S}, \mathrm{S}$ and $\mathrm{S}+\mathrm{R}$ at $\mathrm{P}<0.05,(* *)$ at $\mathrm{P}<0.01,(* * *)$ at $\mathrm{P}<0.001$; $(n=3)$.

\begin{tabular}{cc}
\hline Sample & $\mathrm{A}_{500} / \mathrm{mg}$ of extract \\
\hline $\mathrm{C}$ & $0.15( \pm 0.006)$ \\
$\mathrm{S}$ & $0.02( \pm 0.0022)^{* * *}$ \\
$\mathrm{~S}+\mathrm{R}$ & $0.01( \pm 0.001)^{* *}$ \\
\hline
\end{tabular}


TABLE 3. The total content of tannins according to the BSA precipitation method in extracts of Vitis californica seeds, germinating under optimum conditions (C), osmotic stress conditions (S) and submitted to recovery after the stress $(\mathrm{S}+\mathrm{R})$. An asterisk $\left(^{*}\right)$ marks significant difference between samples: $\mathrm{C}$ and $\mathrm{S}, \mathrm{S}$ and $\mathrm{S}+\mathrm{R}$ at $\mathrm{P}<0.05,(* *)$ at $\mathrm{P}<0.01,(* * *)$ at $\mathrm{P}<0.001 ;(\mathrm{n}=3)$

\begin{tabular}{cc}
\hline Sample & $\mathrm{A}_{510} / \mathrm{mg}$ of extract \\
\hline $\mathrm{C}$ & $0.15( \pm 0.014)$ \\
$\mathrm{S}$ & $0.07( \pm 0.005) * * *$ \\
$\mathrm{~S}+\mathrm{R}$ & $0.05( \pm 0.003) * *$ \\
\hline
\end{tabular}

in seeds germinating under osmotic stress (sample $\mathrm{S}$ ) was much lower, i.e. $0.02 \mathrm{~A}_{500} / \mathrm{mg}$ of extract. Moreover, it continued to decline in seeds submitted to recovery under optimum conditions following osmotic stress treatment. The content of these compounds in sample $\mathrm{S}+\mathrm{R}$ reached barely $0.01 \mathrm{~A}_{500} / \mathrm{mg}$ of extract (Table 2).

The other method used for determination of tannins in the tested biological material was precipitation of tannins with BSA. Changes in the content of tannins in germinating seeds investigated with the vanillin method (Table 2) and precipitation with BSA (Table 3) showed similar tendencies. By using the BSA precipitation method it was demonstrated that the content of tannins was the highest in seeds germinating under optimum conditions (sample C), lower in seeds germinating under osmotic stress (sample $\mathrm{S}$ ) and the lowest while stress treated seeds were undergoing recovery (sample $\mathrm{S}+\mathrm{R}$ ). The concentrations of tannins determined with this method were as follows: 0.15 in sample C, 0.07 in sample $\mathrm{S}$ and $0.05 \mathrm{~A}_{510} / \mathrm{mg}$ of extract in sample $\mathrm{S}+\mathrm{R}$ (Table 3).

Another part of the study concerned changes in the content of catechins. It has been demonstrated that seeds germinating under osmotic stress (sample S) contained more catechins than the ones germinating under optimum conditions (Table 4). The total content of catechin and epicatechin under osmotic stress (sample S) was 0.07 and in seeds germinating under optimum conditions it was $0.05 \mathrm{mg} / \mathrm{g}$ FW. Recovery after osmotic stress (sample $\mathrm{S}+\mathrm{R}$ ) caused depression in the content of catechin and epicatechin (relative to sample S) down to $0.05 \mathrm{mg} / \mathrm{g} \mathrm{FW}$ (Table 4).

The examination of the content of phenolic acids in Vitis californica germinating seeds began with assays on gallic acid. This acid was present in all seed samples, both in its

TABLE 4. The content of catechins in seeds of Vitis californica, germinating under optimum conditions (C), osmotic stress conditions (S) and submitted to recovery after the stress $(\mathrm{S}+\mathrm{R})$. An asterisk $(*)$ marks significant differences between samples: $\mathrm{C}$ and $\mathrm{S}, \mathrm{S}$ and $\mathrm{S}+\mathrm{R}$ at $\mathrm{P}<0.05,(* *)$ at $\mathrm{P}<0.01,(* * *) \mathrm{P}<0.001 ;(\mathrm{n}=3)$.

\begin{tabular}{ccc}
\hline Sample & Phenolic compound & $\mathrm{mg} / \mathrm{g} \mathrm{FW}$ \\
\hline $\mathrm{C}$ & catechin & $0.02( \pm 0.0006)$ \\
& epicatechin & $0.03( \pm 0.0006)$ \\
& total & $0.05( \pm 0.0012)$ \\
$\mathrm{S}$ & catechin & $0.03( \pm 0.0004) * * *$ \\
& epicatechin & $0.04( \pm 0.0008) * * *$ \\
& total & $0.07( \pm 0.0012)^{* * *}$ \\
\hline & catechin & $0.02( \pm 0.0003)^{* * *}$ \\
& epicatechin & $0.03( \pm 0.001)^{* * *}$ \\
& total & $0.05( \pm 0.0013) * * *$
\end{tabular}

TABLE 5. The content of gallic acid: free, liberated from soluble esters and glycosides in Vitis californica seeds, germinating under optimum conditions (C), osmotic stress condition (S) and submitted to recovery after the stress $(\mathrm{S}+\mathrm{R})$. An asterisk $(*)$ marks significant differences between samples: $\mathrm{C}$ and $\mathrm{S}, \mathrm{S}$ and $\mathrm{S}+\mathrm{R}$ at $\mathrm{P}<0.05,(* *)$ at $\mathrm{P}<0.01,(* * *)$ at $\mathrm{P}<0.001 ;(\mathrm{n}=3)$.

\begin{tabular}{ccc}
\hline Sample & Form of phenolic acid & $\mu \mathrm{g} / \mathrm{g} \mathrm{FW}$ \\
\hline \multirow{3}{*}{$\mathrm{C}$} & free & $5.61( \pm 0.14)$ \\
& ester - bound & $31.56( \pm 0.79)$ \\
& glycoside - bound & $5.21( \pm 0.13)$ \\
total & $42.38( \pm 1.06)$ \\
\hline $\mathrm{S}$ & free & $5.11( \pm 0.13)^{*}$ \\
& ester - bound & $31.65( \pm 0.78)$ \\
& glycoside - bound & $5.61( \pm 0.14)^{*}$ \\
total & $42.37( \pm 1.05)$ \\
S+R & free & $4.65( \pm 0.12)^{*}$ \\
& ester - bound & $33.78( \pm 0.84)^{*}$ \\
& glycoside - bound & $3.79( \pm 0.09)^{* *}$ \\
& $42.22 \pm 1.05$ \\
\hline
\end{tabular}

free form and bound to esters and glycosides. The total of all forms of gallic acid in extracts from seeds germinating under different conditions was similar, about $42 \mu \mathrm{g} / \mathrm{g} \mathrm{FW}$ (Table 5). Ester-bound gallic acid was predominant. In samples $\mathrm{C}$ and $\mathrm{S}$, the content of this fraction was similar: 31.21 and $31.65 \mu \mathrm{g} / \mathrm{g} \mathrm{FW}$, respectively. Osmotic stress depressed the contribution of free gallic acid. In sample $\mathrm{C}$ the content of this fraction was 5.61 and in sample $\mathrm{S}$ it fell to $5.11 \mu \mathrm{g} / \mathrm{g} \mathrm{FW}$. Under such conditions, the quantity of glycoside-bound gallic acid increased. The amount of this fraction in sample $C$ was 5.21 and in sample $S-5.61 \mu \mathrm{g} / \mathrm{g}$ FW (Table 5). It is worth adding that during the recovery process after stress the content of gallic acid, both its free form and glycoside-bound one, decreased. Sample S contained 5.11 and $5.61 \mu \mathrm{g} / \mathrm{g} \mathrm{FW}$ of free and glycoside-bound gallic acid, respectively, while the analogous amounts in sample $\mathrm{S}+\mathrm{R}$ were 4.65 and $3.79 \mu \mathrm{g} / \mathrm{g} \mathrm{FW}$. Simultaneously, more ester-bound gallic acid appeared during recovery - its concentration rose from 31.65 (in sample $\mathrm{S}$ ) to $33.78 \mu \mathrm{g} / \mathrm{g}$ FW (in sample $\mathrm{S}+\mathrm{R}$ ) (Table 5). Much less caffeic acid than gallic acid was found in germinating seeds. Under osmotic stress, the total caffeic acid level decreased from 4.26 (in sample C) to $4.18 \mu \mathrm{g} / \mathrm{g} \mathrm{FW}$ (in sample S). Also the free form of this acid fell from $0.59 \mu \mathrm{g} / \mathrm{g} \mathrm{FW}$ (in sample C) to

TABLE 6 . The content of caffeic acid: free, liberated from soluble esters and glycosides in Vitis californica seeds, germinating under optimum conditions (C), osmotic stress condition (S) and submitted to recovery after the stress $(\mathrm{S}+\mathrm{R})$. An asterisk $(*)$ marks significant differences between samples: $\mathrm{C}$ and $\mathrm{S}, \mathrm{S}$ and $\mathrm{S}+\mathrm{R}$ at $\mathrm{P}<0.05,(* *)$ at $\mathrm{P}<0.01,(* * *)$ at $\mathrm{P}<0.001 ;(\mathrm{n}=3)$.

\begin{tabular}{ccc}
\hline Sample & Form of phenolic acid & $\mu \mathrm{g} / \mathrm{g} \mathrm{FW}$ \\
\hline \multirow{3}{*}{$\mathrm{C}$} & free & $0.59( \pm 0.01)$ \\
& ester - bound & $3.67( \pm 0.09)$ \\
total & $4.26( \pm 0.10)$ \\
\hline \multirow{3}{*}{$\mathrm{S}$} & free & \\
& ester - bound & $4.18( \pm 0.18)^{* *}$ \\
& total & $4.18( \pm 0.18)^{*}$ \\
\hline \multirow{3}{*}{$\mathrm{S}+\mathrm{R}$} & free & $0.05( \pm 0.001)$ \\
& ester - bound & $7.17( \pm 0.17)^{* * *}$ \\
& total & $7.22( \pm 0.171)^{* * *}$ \\
\hline
\end{tabular}


trace amounts in sample $\mathrm{S}$ (Table 6). At the same time, the ester-bound form of caffeic acid was observed to have increased under osmotic stress (from 3.67 in sample $\mathrm{C}$ to $4.18 \mu \mathrm{g} / \mathrm{g} \mathrm{FW}$ in sample $\mathrm{S})$. During post-stress recovery, a large increase in the total content of caffeic acid occurred in germinating seeds. In sample $\mathrm{S}$ all caffeic acid was ester-bound. The total content of caffeic acid in sample $\mathrm{S}$ was $4.18 \mu \mathrm{g} / \mathrm{g}$ FW. In sample $\mathrm{S}+\mathrm{R}$ it increased to $7.22 \mu \mathrm{g} / \mathrm{g}$ $\mathrm{FW}$, of which most $(7.17 \mu \mathrm{g} / \mathrm{g} \mathrm{FW})$ belonged to the esterbound fraction (Table 6). Moreover, no glycoside-bound caffeic acid was found in any of the tested samples.

The results of assays on the content of $p$-coumaric acid in germinating $V$. californica seeds can be seen in Table 7 . Osmotic stress caused a significant decrease in the total content of this acid in seeds and in its ester- and glycosidebound forms. In sample $\mathrm{C}$, the total content of $p$-coumaric acid, its free form and ester-bound fraction reached, respectively, 6.86, 1.11 and $5.75 \mu \mathrm{g} / \mathrm{g} \mathrm{FW}$, whereas sample S contained $4.53 \mu \mathrm{g} / \mathrm{g} \mathrm{FW}$ of $p$-coumaric acid, all of which was ester-bound. During the recovery after stress, the content of $p$-coumaric acid increased. In sample $\mathrm{S}+\mathrm{R}$ there was 0.08 of free acid, 6.06 of ester-bound form and $6.14 \mu \mathrm{g} / \mathrm{g}$ $\mathrm{FW}$ of total $p$-coumaric acid. Analogously to caffeic acid, the ester-bound form was the predominant fraction of $p$ -coumaric acid. Likewise, no presence of this acid in its glycoside-bound form was determined (Table 7).

Among the phenolic acids detected in grapevine seeds, ferulic acid appeared in the smallest quantities, both in the free form and as an ester-bound compound (Table 8). The highest total content of ferulic acid was found in seeds germinating under optimum conditions (sample C, $0.91 \mu \mathrm{g} / \mathrm{g}$ FW). Osmotic stress depressed the total content of ferulic acid in germinating seeds (sample $\mathrm{S}-0.62 \mu \mathrm{g} / \mathrm{g} \mathrm{FW}$ ). Worth noticing is the fact that ferulic acid occurred mainly as an ester-bound compound, and its free form was detected only in sample $\mathrm{C}$, where it made up $0.17 \mu \mathrm{g} / \mathrm{g} \mathrm{FW}$. During the recovery process after stress, the amount of this acid in germinating seeds continued to decline (sample $\mathrm{S}+\mathrm{R}-0.34 \mu \mathrm{g} / \mathrm{g} \mathrm{FW}$ ).

The capacity to scavenge $\mathrm{DPPH}^{\bullet}$ free radicals by extracts from $V$. californica seeds is illustrated in Figue 1. All the tested extracts had antiradical activity. The samples possessing the highest antioxidant activity were characterised by the lowest absorbance. Extracts from seeds which germinated under optimum conditions (sample C)
TABLE 7. The content of $p$-coumaric acid: free, liberated from soluble esters and glycosides in Vitis californica seeds, germinating under optimum conditions (C), osmotic stress condition (S) and submitted to recovery after the stress $(\mathrm{S}+\mathrm{R})$. An asterisk $(*)$ marks significant differences between samples: $\mathrm{C}$ and $\mathrm{S}, \mathrm{S}$ and $\mathrm{S}+\mathrm{R}$ at $\mathrm{P}<0.05,\left({ }^{*}\right)$ at $\mathrm{P}<0.01,(* * *)$ at $\mathrm{P}<0.001 ;(\mathrm{n}=3)$.

\begin{tabular}{ccc}
\hline Sample & Form of phenolic acid & $\mu \mathrm{g} / \mathrm{g} \mathrm{FW}$ \\
\hline & free & $1.11( \pm 0.03)$ \\
$\mathrm{C}$ & ester - bound & $5.75( \pm 0.14)$ \\
& total & $6.86( \pm 0.17)$ \\
\hline & free & \\
$\mathrm{S}$ & ester - bound & $4.53( \pm 0.11)^{* *}$ \\
& total & $4.53( \pm 0.11)^{* * *}$ \\
\hline & free & $0.08 \pm 0.001$ \\
$\mathrm{~S}+\mathrm{R}$ & ester - bound & $6.06( \pm 0.15)^{* * *}$ \\
& total & $6.14( \pm 0.15)^{* * *}$ \\
\hline
\end{tabular}

TABLE 8. The content of ferulic acid: free, liberated from soluble esters and glycosides in Vitis californica seeds, germinating under optimum conditions (C), osmotic stress condition (S) and submitted to recovery after the stress $(\mathrm{S}+\mathrm{R})$. An asterisk $\left(^{*}\right)$ marks significant differences between samples: $\mathrm{BS}$ and $\mathrm{S}, \mathrm{S}$ and $\mathrm{S}+\mathrm{R}$ at $\mathrm{P}<0.05,(* *)$ at $\mathrm{P}<0.01,(* * *)$ at $\mathrm{P}<0.001 ;(\mathrm{n}=3)$.

\begin{tabular}{ccc}
\hline Sample & Form of phenolic acid & $\mu \mathrm{g} / \mathrm{g} \mathrm{FW}$ \\
\hline \multirow{3}{*}{$\mathrm{C}$} & free & $0.17( \pm 0.003)$ \\
& ester - bound & $0.74( \pm 0.02)$ \\
total & $0.91( \pm 0.02)$ \\
\hline & free & \\
$\mathrm{S}$ & ester - bound & $0.62( \pm 0.01)^{*}$ \\
& total & $0.62( \pm 0.01)^{* *}$ \\
\hline & free & \\
$\mathrm{S}+\mathrm{R}$ & ester - bound & $0.34( \pm 0.007)^{* *}$ \\
& total & $0.34( \pm 0.007)^{* *}$ \\
\hline
\end{tabular}

were stronger antioxidants than seeds subjected to osmotic stress (sample S). At a concentration of $0.5 \mathrm{mg}$ extract per sample, extracts from seeds submitted to osmotic stress were characterised by higher absorbance at $\mathrm{A}_{517}$ than extracts from seeds germinating under optimum conditions (sample $\mathrm{C}-0.12$, sample $\mathrm{S}-0.34$ ). Extracts from seeds submitted to recovery $(\mathrm{S}+\mathrm{R})$ were able to scavenge free radicals more efficiently than extracts from seeds germinat-

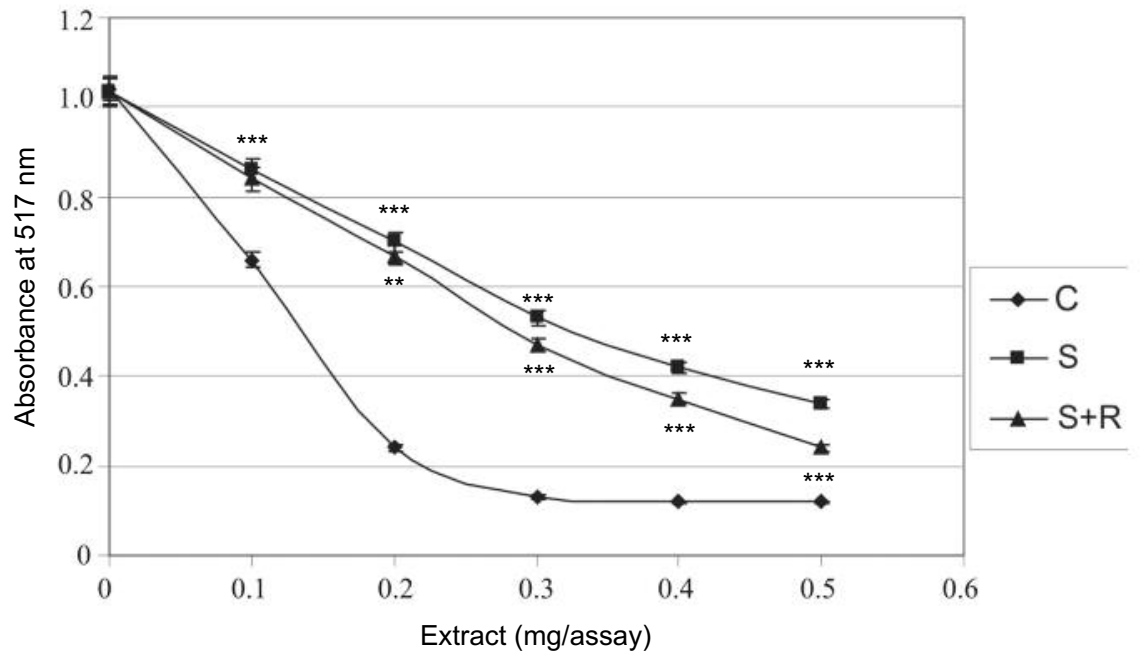

Fig. 1. Scavenging effect on $\mathrm{DPPH}^{\bullet}$ radical of extracts of Vitis californica seeds, germinating under optimum conditions (C), osmotic stress conditions (S) and submitted to recovery after the stress $(\mathrm{S}+\mathrm{R})$. Vertical lines mark standard deviations $( \pm \mathrm{SE}, \mathrm{n}=3$ ). An asterisk $\left(^{*}\right)$ marks significant differences between samples: $\mathrm{C}$ and $\mathrm{S}, \mathrm{S}$ and $\mathrm{S}+\mathrm{R}$ at $\mathrm{P}<0.05,(* *)$ at $\mathrm{P}<0.01,(* * *)$ at $\mathrm{P}<0.001$; $(\mathrm{n}=3)$. 


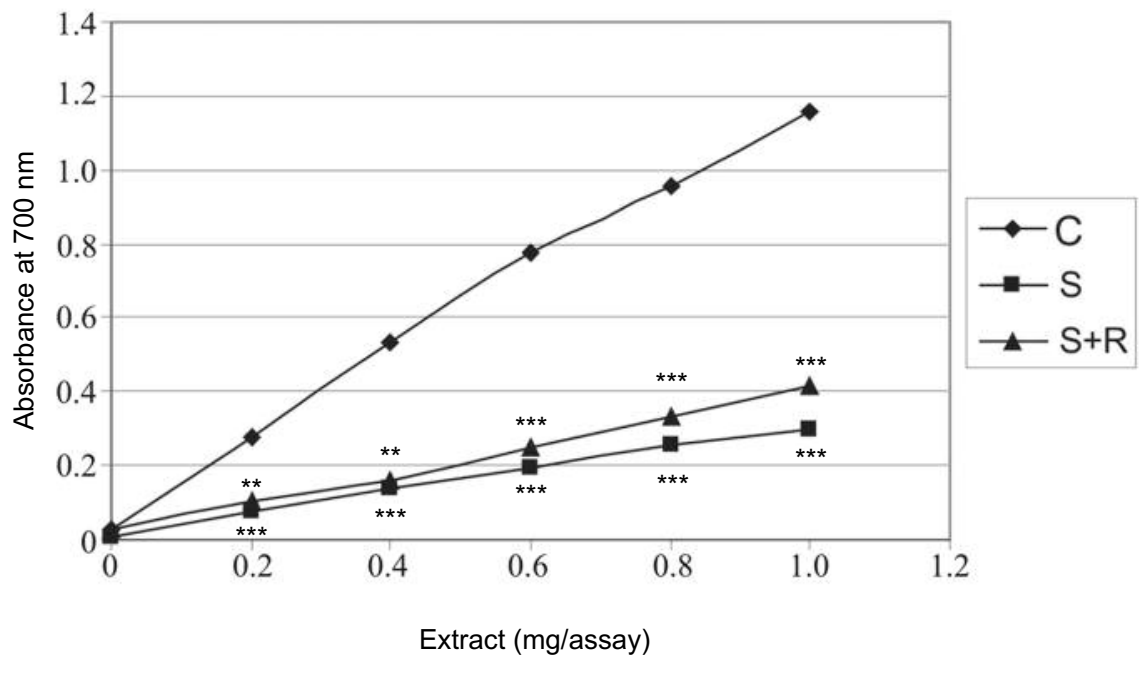

Fig. 2. Reducing power of acetone extracts of Vitis californica seeds germinating under optimum conditions (C), osmotic stress conditions (S) and submitted to recovery after the stress $(\mathrm{S}+\mathrm{R})$. Vertical lines mark standard deviations $( \pm \mathrm{SE}, \mathrm{n}=3)$. An asterisk $(*)$ marks significant differences between samples: BS and $\mathrm{S}, \mathrm{S}$ and $\mathrm{S}+\mathrm{R}$ at $\mathrm{P}<0.05,(* *)$ at $\mathrm{P}<0.01$, $(* * *)$ at $\mathrm{P}<0.001 ;(\mathrm{n}=3)$. ing under osmotic stress (S). The absorbance for sample $\mathrm{S}+\mathrm{R}$ at an extract concentration of $0.5 \mathrm{mg} / \mathrm{sample}$ was 0.25 . The results indicate that under stress conditions synthesis of antioxidant compounds is depressed, but becomes more intensive during recovery after stress.

The results on the reduction power of extracts from $V$. californica seeds are presented in Figure 2. It has been found out that all the seed extracts possessed reducing properties. The reducing power of extracts from seeds germinating under optimum conditions (sample C) was much higher than the reducing power of extracts from seeds germinating under stress conditions (sample $\mathrm{S}$ ). For $\mathrm{A}_{700}$, at a concentration of $1 \mathrm{mg} / \mathrm{sample}$, this value reached 1.18 for the control sample (C) and 0.3 for a sample subjected to osmotic stress (S). Extracts from germinating seeds subjected to osmotic stress and then to a recovery period (sample $\mathrm{S}+\mathrm{R}$ ) revealed increasing reducing power, which reached 0.4 for $\mathrm{A}_{700}$ at an extract concentration of $1 \mathrm{mg} / \mathrm{sample}$. This suggests that stress conditions significantly depress the content of reducing compounds in germinating seeds, but during recovery under optimum conditions following osmotic stress they are synthesised more intensively.

The results on the antioxidant capacity of extracts from germinating $V$. californica seeds, expressed as Trolox equivalents (TEAC), are presented in Table 9. In the method for determination of antioxidant capacity, a colour solution of $\mathrm{ABTS}^{+} \bullet$ free radical was used. It has been demonstrated that all the extracts from the tested seeds are capable of scavenging $\mathrm{ABTS}^{+} \bullet$ free radical, with the extracts from seeds germinating under osmotic stress (sample S) characterized by a much lower TEAC capacity than seeds germinating under optimum conditions (sample $\mathrm{C}$ ).

TABLE 9. Trolox equivalent antioxidant capacity (TEAC) of extract of Vitis californica seeds germinating under optimum conditions (C), osmotic stress conditions $(\mathrm{S})$ and submitted to recovery after the stress $(\mathrm{S}+\mathrm{R})$. An asterisk (*) marks significant differences between samples: BS and $\mathrm{S}$, $\mathrm{S}$ and $\mathrm{S}+\mathrm{R}$, at $\mathrm{P}<0.05,(* *)$ at $\mathrm{P}<0.01$, at $(* * *) \mathrm{P}<0.001 ;(\mathrm{n}=3)$.

\begin{tabular}{cc}
\hline Sample & Antioxidant activity $(\mathrm{mM}$ of Trolox/g extract) \\
\hline $\mathrm{C}$ & $1.11( \pm 0.05)$ \\
$\mathrm{S}$ & $0.19( \pm 0.008) * * *$ \\
$\mathrm{~S}+\mathrm{R}$ & $0.25( \pm 0.01)^{*}$ \\
\hline
\end{tabular}

For extracts from seeds submitted to osmotic stress (sample $\mathrm{S}$ ), the determined value of TEAC capacity was 0.19 , as compared to $1.11 \mathrm{mM}$ Trolox/g extract for sample C. Extracts from seeds undergoing recovery after stress (sample $\mathrm{S}+\mathrm{R}$ ) had greater capability to scavenge $\mathrm{ABTS}^{+} \bullet$ free radical than seeds germinating under osmotic stress (sample $\mathrm{S}$ ). As mentioned above, the TEAC value for sample $\mathrm{S}$ was 0.19 and that for sample $\mathrm{S}+\mathrm{R}$ reached $0.25 \mathrm{mM}$ Trolox/g extract.

\section{DISCUSSION}

Osmotic stress inhibits the total synthesis of phenolic compounds. It was shown previously in extracts from germinating seeds of Vitis amurensis (Weidner et al. 2007). This finding has been confirmed by this present study, conducted on seeds of Vitis californica. Similar results were also obtained in our earlier research on the influence of other abiotic stresses on plants. For example, in roots of seedlings of Vitis vinifera exposed to chill stress, the total content of phenolics, tannins and phenolic acids was lower than in the control (Weidner et al. 2009b). Also in leaves of Vitis vinfera depressed levels of phenolic compounds and tannins were observed as a result of low temperature stress (Amarowicz et al. 2010). In contrast, Rudikovskaya et al. (2008) found out that low temperature did not have any larger effect on the total content of phenolic compounds in pea roots, but it considerably decreased the content of flavon in the early development of pea roots. Other experiments have demonstrated that enforced dehydration treatment caused a depression in the content of phenolic compounds in rye caryopses and triticale caryopses (Weidner et al. 2000, 2002). Many tests have implied that production of phenols in plant tissues rises under stress conditions (Dixon and Paiva 1995; Solecka 1997; Janas et al. 2002; Wróbel et al. 2005; Weidner et al. 2009a). Such discrepancies in experimental results can be attributed to differences in abiotic stresses, e.g. type of stress, its intensity, moment of action (the least tolerant to stress are the early stages of germination and plant development) and tested biological material, e.g. whole seedlings or different parts of plants, such as roots or leaves (characterized by great diversity of secondary metabolites). In the present study, an increase in 
the total content of phenolic compounds has been observed during the recovery period after osmotic stress. Higher total content of phenolic compounds as well as some phenolic acids (including $p$-coumaric, ferulic and caffeic acids) during recovery after chill stress $\left(+10^{\circ} \mathrm{C}\right)$ was likewise demonstrated in previous studies (Amarowicz et al. 2010; Weidner et al. 2009b). This may be indicative of a very important role of phenolic compounds in recovery reactions, which take place in plant cells after stress.

Grapevine seeds are a rich source of condensed tannins (proanthocyanidins) and their monomers, such as catechins (Pekić et al. 1998; Sun et al. 1998; Jayaprakasha et al. 2003). In the present study, the content of tannins was determined with two methods: the vanillin test and precipitation of tannins together with BSA. It has been demonstrated that osmotic stress caused a decrease in the content of tannins in germinating seeds of Vitis californica. Similar results were obtained in our previous tests on seeds of Vitis amurensis (Weidner et al. 2007). The content of tannins (determined by either of the methods) declined considerably in seeds of Vitis riparia also under the influence of chill stress (Wróbel et al. 2005). In leaves of Vitis vinifera exposed to low temperature, the content of condensed tannins likewise fell down (Amarowicz et al. 2010). In a study on the effect of low temperature stress on the growth of Vitis vinifera seedlings, it was observed that the content of condensed tannins (determined with the vanillin assay) declined in grapevine roots in response to the stress, whereas the content of condensed and hydrolyzing tannins (determined with the BSA precipitation method) rose under chill stress (Weidner et al. 2009b). This different response can be due to the excessively low mass of tannin monomers in a solution after BSA protein precipitation (Hagerman and Butler 1978). The process of recovery after osmotic stress, observed in this study, led to a further decrease in the content of tannins (as determined with both methods) in germinating seeds of Vitis californica. In turn, our previous results suggest that the content of tannins rises demonstrably during the recovery process after chill stress determined with the vanillin method (Amarowicz et al. 2010) or the vanillin method and precipitation of tannins together with BSA (Weidner et al. 2009b).

The components of condensed tannins in grapevine seeds are (present as monomers) catechin and epicatechin. When Vitis californica seeds were germinating under osmotic stress, a large increase was observed in the content of catechins (catechin + epicatechin) relative the control. In contrast, the post-stress recovery process depressed the content of these substances. More catechins in samples exposed to stress versus the samples of plants growing under optimal conditions had been detected earlier (Wróbel et al. 2005; Weidner et al. 2007). It can be suspected that stresses lead to decomposition of tannins, which results in an increase in the content of catechins in tissues. Free catechins can probably be more actively engaged in counteracting oxidative stress, which is a secondary stress, and the accompanying abiotic stress, i.e. drought, low or high temperature, salinity. It is probable that catechins and epicatechins have strong antioxidant properties - they scavenge free radicals 18-fold more efficiently than ascorbic acid (Oszmiański and Lamer-Zarawska 1993). Fauconneau et al. (1997) proved that catechins are twice as active as epicatechins. According to Bewley and Black (1994) catechin group compounds and their polymers can also inhibit germination of many seeds.

Four phenolic acids were identified in Vitis californica seeds: gallic, caffeic, $p$-coumaric and ferulic. The most abundant was gallic acid, while ferulic acid appeared in the lowest concentration. Caffeic, $p$-coumaric and ferulic acids appeared only as ester-bound form, which had already been demonstrated in our previous studies (Weidner et al. $2009 \mathrm{a} / \mathrm{b}$ ). Gallic acid was found in both ester- and glycoside-bound forms, with the ester-bound form being much more abundant than the glycoside-bound form, the finding that had been indicated by other authors, for example Wróbel et al. (2005) and Amarowicz et al. (2010). Worth noticing is the fact that gallic acid was found to be most abundant in Vitis riparia seeds (Wróbel et al. 2005). In Vitis amurensis seeds, however, the presence of gallic acid in the glycoside-bound form was discovered only after a prolonged, i.e. over 10 days, germination of seeds under optimum conditions (Weidner et al. 2007). Solecka (1997) claims that presence of larger concentrations of phenolic acids in ester- or glycoside-bound forms in tissues is less toxic to plants. It has been observed that the content of glycoside-bound gallic acid rose after exposure to osmotic stress, but fell down during the post-stress recovery period. Wróbel et al. (2005) found that the content of glycosidebound form of gallic acid during chill stress was lower than in the control sample, in which it was similar to the esterbound form of this acid. Contrary to that, the free form of this acid increased in response to low temperature (Wróbel et al. 2005). In the present research, the ester-bound forms of gallic and caffeic acids were found to have risen, while their free form fell in concentration in seeds exposed to stress. Osmotic stress also caused the lowering of the free and ester bound forms of $p$-coumaric and ferulic acids. Depressed levels of the ester-bound form of $p$-coumaric, ferulic and caffeic acids have also been observed in roots of Vitis vinifera exposed to chill stress. Tissues of such roots contained most of $p$-coumaric acid and least of caffeic acid (Weidner et al. 2009b). In leaves of Vitis vinifera exposed to low temperature, the content of ester- and glycoside-bound gallic, caffeic and ferulic acid rose, while that of $p$-coumaric acid declined (Amarowicz et al. 2010). Also in seeds of rye and triticale the free and bound (to ester or glycoside) forms of acids, including $p$-coumaric, ferulic and sinapinic acids under the effect of dehydratation (Weidner et al. 2000, 2002). In our earlier studies on seedlings of Vitis amurensis exposed to osmotic stress, a lower content of the free-and ester-bound forms of gallic acid, ester-bound form of caffeic acid and complete lack of accumulation of the bound form of $p$-coumaric acid was noticed (Weidner et al. 2007). Low content of the free and ester-bound form of $p$-coumaric acid was also observed in response to chill stress (Wróbel et al. 2005). In our study, the post-stress recovery process caused an increase in the content of the free and ester-bound forms of caffeic and $p$ -coumaric acids in germinating seeds of Vitis californica. Also, an increase in the content of ester-bound gallic acid, accompanied by a decrease in its free form, was observed. The post-stress recovery process decreased the ester-bound form of ferulic acid. Increased concentrations of esterbound forms of $p$-coumaric, caffeic and ferulic acids during recovery from chill stress had been previously detected in roots of Vitis vinifera (Weidner et al. 2009b). Besides, 
Amarowicz et al. (2010) found elevated content of the ester- and glycoside-bound forms of gallic, caffeic, $p$ -coumaric and ferulic acids in leaves of Vitis vinifera during recovery after low temperature stress. However, when seeds recovered from drought stress, it was only caffeic acid that increased in grapevine roots, while the content of $p$-coumaric and ferulic acids fell (Weidner et al. 2009a). It can be suspected that phenolic acids (mainly their esterbound forms), which increase in concentration during recovery, may perform important protective functions during regenerative processes in cells. Maniak and Targoński (1996) discovered that esters of ferulic and caffeic acids, orginating from oat extracts, possess considerable antioxidant potential.

In the present study, the antioxidant activity of extracts made from Vitis californica seeds was determined. It was demonstrated that all extracts were active antioxidants. However, extracts from seeds germinating under optimum conditions proved to be more efficient in scavenging DPPH free radicals and had a higher reduction power than extracts from seeds exposed to osmotic stress. This finding may evidence that tissues of germinating seeds subjected to stress contain less of antioxidants and reducing compounds. However, during the regeneration process after osmotic stress, the aforementioned capabilities of extracts from germinating seeds (previously exposed to water stress) increased. Similar results were obtained in tests on roots of Vitis vinifera exposed to drought stress or low temperature and during the recovery processes following such (Weidner et al. 2009a/b). Depressed antioxidant activity has also been noticed in Vitis amurensis under the influence of osmotic stress (Weidner et al. 2007) or in Vitis vinifera leaves in response to low temperature (Amarowicz et al. 2010). This might imply that grapevine tolerance to drought stress is most probably connected with the extent of antioxidant potential in plant tissues. For example, the strongest antioxidant potential is found in seeds of grapevine which contain high amounts of phenolic compounds, mainly catechins (Pastrana-Bonilla et al. 2003; Amarowicz et al. 2004). This positive correlation between the content of phenolic compounds in extracts and their antioxidant activity and reduction power has been demonstrated in the present paper as well as in some preceding tests (Alonso et al. 2002; Caillet et al. 2006; Weidner et al. 2009b). One can conclude that osmotic stress inhibits in germinating seeds the activity of enzymes which participate in antioxidizing activity. Thus, the antioxidant protection of a plant becomes largely restrained under the effect of osmotic stress. Therefore, it seems that a high oxidation-reduction potential which occurs even before the stress appears as well as during the post-stress recovery helps to maintain proper homeostasis of oxidation and reduction reactions. This, eventually, enables plants to survive under unfavourable environmental conditions.

\section{LITERATURE CITED}

ALONSO A.M., GUILLEN D.A., BARROSO C.G., PUERTAS B., GARCIA A. 2002. Determination of antioxidant activity of wine by products and its correlation with polyphenolic content. J. Agric. Food Chem. 50: 5832-5836.

AMAROWICZ R., WEIDNER S. 2009. Biological activity of grapevine phenolics compounds. In: K.A. Roubelakis-Ange- lakis (eds), Grapevine Molecular Physiology \& Biotechnology, 2nd, edn. Springer Science + Business Media B.V.: 389-405, DOI 10.1007/978-90-481-2305-6-14.

AMAROWICZ R., WEIDNER S., WÓJTOWICZ I., KARAMAĆ M., KOSIŃSKA A., RYBARCZYK A. 2010. Influence of low-temperature stress on changes in the composition of grapevine leaf phenolic compounds and their antioxidant properties. Funct. Plant Sci. Biot. 4: 90-96.

AMAROWICZ R., PEGG R.B., RAHIMI-MOGHADDAM P., WEIL J.A. 2004. Free-radical scavenging capacity and antioxidant activity of selected plant species from the Canadian prairies. Food Chem. 84: 551-562.

AMAROWICZ R., WEIDNER S. 2001. Content of phenolic acids in rye caryopses determined using DAD-HPLC method. Czech. J. Food Sci. 19: 201-205.

AMAROWICZ R., NACZK M., ZADERNOWSKI R., SHAHIDI F. 2000. Antioxidant activity of condensed tannins of beach pea, canola hulls, evening primrose, and faba beans. J. Food Lipids 7: 199-211.

AMAROWICZ R., PISKUŁA M., HONKE J., RUDNICKA B., TROSZYŃSKA A., KOZŁOWSKA H. 1995. Extraction of phenolic compounds from lentil seeds (Lens culinaris) with various solvents. Pol. J. Food Nutr. Sci. 4/45: 53-62.

BEWLEY J.D., BLACK M. 1994. Seeds: Physiology of development and germination. Plenum Press. New York and London.

BLOKHINA O., VIROLAINEN E., FAGERSTEDT K.V. 2003. Antioxidants, oxidative damage and oxygen deprivation stress: a review. Ann. Bot. 91: 179-194.

BOHNERT H.J., NELSON D.E., JENSEN R.G. 1995. Adaptation to environmental stresses. Plant Cell, 7: 1099-1111.

CAILLET S., SALMIERI S., LACROIX M. 2006. Evaluation of free radical-scavenging properties of commercial grape phenol extracts by a fast colorimetric method. Food Chem. 95: 1-8.

DIXON R.D., PAIVA N.L. 1995. Stress-induced phenylopropanoid metabolism. Plant Cell 7: 1085-1097.

FAUCONNEAU B., WAFFO T.P., HUGUET F., BARRIER L., DECENDIT A., MERILLON J.M. 1997. Comparative study of radical scavenger and antioxidant properties of phenolic compounds from Vitis vinifera cell structures using in vitro tests. Life Sci. 61: 2103-2110.

GWÓŹDŹ E.A. 1996. Molekularne podstawy odpowiedzi roślin na stresy środowiskowe. In: J. Barciszewski, K. Łastowski, T. Twardowski (ed.), Nowe tendencje w biologii molekularnej i inżynierii genetycznej oraz medycynie. Poznań. 496-492.

HAGERMAN A., BUTLER L. 1978. Protein precipitation method for quantitative determination of tannins. J. Agric. Food Chem. 26: 809-811.

HARBORNE J.B. 1980. Plant phenolics. In: Bell E.A., Charlwood B.V. (eds), Encyclopedia of Plant Physiology Series 8. Pp. 329-402.

JANAS K.M., CVIKROVA M., PAŁĄGIEWICZ A., SZAFRAŃSKA K., POSMYK M.M. 2002. Constitutive elevated accumulation of phenylopropanoids in soybean roots at low temperature. Plant Sci. 163: 369-373.

JAYAPRAKASHA G.K., SELVI T., SAKARIAH K.K. 2003. Antibacterial and antioxidant activities of grape (Vitis vinifera) seeds extract. Food Res. Inter. 36: 117-122.

KELES Y., ONCEL I. 2002. Response of antioxidative defence system to temperature and water stress combinations in wheat seedlings. Plant Sci. 163: 783-90.

KRANNER I., BECKETT R.P., WORNIK S., ZORN M., PFEIFHOFER H.W. 2002. Revival of a resurrection plant correlates with its antioxidant status. Plant J. 31: 13-24.

KRYGER K., SOSULSKI F.W., HOGGE L. 1982. Free, esterified, and insoluble-bound phenolic acids. 1. Extraction and purification procedure. J. Agric. Food. Chem. 30: 330-334.

MANIAK B., TARGOŃSKI Z. 1996. Przeciwutleniacze naturalne występujące w żywności. Przem. Ferm. Owoc. Warz. 40 (4):7-10. 
MITTLER R. 2002. Oxidative stress, antioxidants and stress tolerance. Trends Plant Sci. 7: 405-10.

NACZK M., SHAHIDI F. 1989. The effect of methanol-ammonia-water treatment on the content of phenolic acids of canola. Food Chem. 31: 159-164.

NEGRO C., TOMMASI L., MICELI A. 2003. Phenolic compounds and antioxidant activity from red grape marc extracts. Bioresour. Technol. 87: 41-44.

OH M.M., TRICK H.N., RAJASHEKAR C.B. 2009. Secondary metabolism and antioxidants are involved in environmental adaptation and stress tolerance in lettuce. J. Plant Physiol. 166: 180-191.

OSZMIAŃSKI J. 1995. Polifenole jako przeciwutleniacze w żywności. Przem. Spoż. 3: 94-96.

OSZMIANSKI J., BOURZEIX M. 1995. Preparation of catechin and procyanidin standars from hawthorn (Crataegus azarolus L.) and pine (Pine mesogeensis fieschi) barks. Pol. J. Food Nutr. Sci. 4/45: 89-96.

OSZMIAŃSKI J., LAMER-ZARAWSKA E. 1993. Występowanie i znaczenie tanin w roślinach leczniczych. Wiad. Zielar. 35: 16-17.

PEKIĆ B., KOVAĆ V., ALONSO E., REVILLA E. 1998. Study of extraction of proanthocyanidins from grape seeds. Food Chem. 61: 201-206.

PASTRANA-BONILLA E., AKOH C.C., SELLAPPAN S., KREWET G. 2003. Phenolic content and antioxidant capacity of muscadine grapes. J. Agric. Food Chem. 51: 5497-5503.

PISKORNIK Z. 1994. Fizjologia roślin. Wyd. AR w Krakowie. Kraków.

PRICE N.J., VAN SCOYOC S., BUTLER L.G. 1978. A critical evaluation of the vanillic reactions an assay for tannin in sorghum grain. J. Agric. Food Chem. 26: 1214-1218.

RE R., PELLEGRINI N., PROTEGGENTE A., PANNALA A., YANG M., RICE-EVANS C. 1999. Antioxidant activity applying an improved ABTS radical cation decolorization assay. Free Rad. Biol. Med. 26: 1231-1237.

RUDIKOVSKAYA E.G., FEDOROVA G.A., DUDAREVA L.V., MAKAROVA L.E., RUDIKOVSKIJ A.V. 2008. Effect of growth temperature on the composition of phenols in pea roots. Rus. J. Plant Phsiol. 55: 712-715.

SMIRNOFF N. 1998. Plant resistance to environmental stress. Curr. Opin. Biotechnol. 9: 214-9.

SOKÓŁ-ŁĘTOWSKA A. 1997. Próby opracowania i zastosowania preparatów związków fenolowych wybranych surowców roślinnych jako przeciwutleniaczy. Zeszyty Naukowe Akademii Rolniczej we Wrocławiu. Technologia Żywności XI, 319: 99-115.
SOLECKA D. 1997. Role of phenylopropanoid compounds in plant responses to different stress factors. Acta Physiol. Plant. 19: $257-268$.

SREERAMULU N. 1983. Auxins, inhibitors, and phenolics in bambarranut seeds (Voandzeia subterranea Thouars) in relation to loss of viability during storage, Ann. Bot. 51: 209-216.

SUN B., LEANDRO C., DA SILVA J.M.R., SPRANGER I. 1998. Separation of grape and wine proanthocyanidins according to their degree of polymerization. J. Agric. Food Chem. 46: 1390-1396.

WEIDNER S., KAROLAK M., KARAMAĆ M., KOSIŃSKA A., AMAROWICZ R. 2009a. Phenolic compounds and properties of antioxidants in grapevine roots (Vitis vinifera L.) under drought stress followed by recovery. Acta Soc. Bot. Pol. 78: 97-103.

WEIDNER S., KORDALA E., BROSOWSKA-ARENDT W., KARAMĆ M., KOSIŃSKA A., AMAROWICZ R. 2009b. Phenolic compounds and properties of antioxidants in grapevine roots (Vitis vinifera L.) under low-temperature stress followed by recovery. Acta Soc. Bot. Pol. 78: 279-286.

WEIDNER S., KARAMAĆ M., AMAROWICZ R., SZYPULSKA E., GOŁGOWSKA A. 2007. Changes in composition of phenolic compounds and antioxidant properties of Vitis amurensis seeds germinated under osmotic stress. Acta Physiol. Plant. 29: 283-290.

WEIDNER S., KRUPA U., AMAROWICZ R., KARAMAĆ M., ABE S. 2002. Phenolic compounds in embryos of triticale caryopses at different stages of development and maturation in normal environment and after dehydration treatment. Euphytica 126: 115-122.

WEIDNER S., AMAROWICZ R., KARAMAĆ M., FRACZZEK E. 2000. Changes in endogenous phenolic acids during development of Secale cereale caryopses and after dehydration treatment of unripe rye grains. Plant Physiol. Biochem. 38: 595-602.

WRÓBEL M., KARAMAĆ M., AMAROWICZ R., FRĄCZEK E., WEIDNER S. 2005. Metabolism of phenolic compounds in Vitis riparia seeds during stratification and during germination under optimal and low temperature stress conditions. Acta Physol. Plant. 27: 313-320.

YEN G.C., CHEN H.Y. 1995. Antioxidant activity of various tea extracts in relation to their antimutagenicity. J. Agric. Food Chem. 43: 27-32.

ZADERNOWSKI R., KOZŁOWSKA H. 1983. Phenolic acids in soybean and rapeseed flours. Lebensm. Wiss. Technol. 16: 110-114. 